\title{
Ciało w procesie konstruowania tożsamości
}

\section{KEYWORDS}

somatic turn, reflexive identity project, extreme metamorphosis, the body in the cultural constructivism, integral life practice

\begin{abstract}
Marzec Jarosław, Ciało $w$ procesie konstruowania tożsamości [The body in the process of constructing identity]. Kultura - Społeczeństwo - Edukacja nr 2(14) 2018, Poznań 2018, pp. 259-284, Adam Mickiewicz University Press. ISSN 2300-0422. DOI 10.14746/kse.2018.14.18.
\end{abstract}

The main intention of my text is to describe the specific of the somatic turn of cultural studies and, to follow Chris Barker's proposition, "the desire to understand the ways in which the body becomes the object of shaping and disciplining by social and cultural forces - i.e. how the body acquires meaning in contemporary culture". The above problem provokes the consideration of the mutual relationships between the culture of late modernity and the category of identity (especially the body in the process of identity construction). The goal outlined in this way aims to present contexts and space for the manifestation of the issues of the body in contemporary culture, The aim of the proposed deliberations is to present the problem of the body from the perspective of reflexive identity (A. Giddens), constructivism perspective (Z. Melosik, A. Gromkowska, M. Bogunia-Borowska), in selected therapeutic systems (J. Kabat-Zinn, A. Lowen, S.\&C. Block) and in the final section I present the category of the body in the integral approach to development (K. Wilber). Also, I shortly summarize my analysis and I point to the dangers of the presented approaches especially in the dominant instant culture practices.

Niniejszy artykuł chcę zadedykować wszystkim, którzy, podobnie jak przytaczani w nim autorzy, przejęli się stanem kultury Zachodu i tropią ślady obecnego kryzysu naszej tożsamości, przejawiającego się, między innymi, bezradnością miesz- 
kańców świata zachodniego wobec negatywnych następstw pięknej, zaawansowanej cywilizacji. Zgodnie z tym konstruktywne wydaje się dzisiaj odwołanie do tradycji Wschodu, skąd w XX wieku przybyła do naszego kręgu cywilizacyjnego idea uważności, idea wywodząca się z tradycji buddyzmu. Owocem tego spotkania dwóch kultur jest wiele interesujących interakcji umysłowości wschodniej i zachodniej. W tekście pragnę przyjrzeć się pewnym trendom w procesie aplikacji, przeszczepu idei uważności na glebie zachodniej racjonalności. Oczywiście jest to zaledwie przyczynek do pogłębionych analiz kulturowych tego procesu, zdaje się także, że tekst ten wpisuje się w nurt badań nad transformacją i wzajemnym oddziaływaniem obydwu tradycji.

Druga rewolucja w psychologii, czyli pojawienie się psychologii humanistycznej, wprowadziła do dyskursu społecznego nowe zagadnienia, a wśród nich szeroką problematykę zdrowia całej osobowości człowieka, twórczość jako kategorię egzystencjalną, kategorię rozwoju integralnego, o którym ostatnio twórczo pisze Ken Wilber, znany na świecie filozof i transpersonalny psycholog. Wraz z postulatem psychologów humanistycznych, by zasięgiem swojego oglądu objąć całe szerokie spektrum świadomości ludzkiej i wraz z postulatem „realizmu”, więcej uwagi zyskała za tym „pozytywna” strona życia. Wielu badaczy zajmuje się obecnie badaniem psychologicznych procesów tego, co nazywamy sukcesem lub szczęściem w życiu. Tak też pojęcia te zagościły najpierw w pismach psychologów humanistycznych, takich jak: Erich Fromm, Rollo May, Abraham Maslow, Carl Rogers, a z żyjących jeszcze badaczy głównie Ken Wilber i Mihaly Csikszentmihalyi eksploatują tę stronę ludzkiej egzystencji. Pojęcia te stopniowo przecierały sobie szlak do zbiorowej wyobraźni i zagościły obecnie w wielu przekazach medialnych, a w kulturze instant przybierają postać gotowych recept na udane życie. Wiedza psychologiczna znalazła szerokie grono propagatorów, tym samym rynek ekspertów wspiera i napędza rozwój tych analitycznych studiów.

Uważna lektura kanonicznych prac z zakresu studiów kulturowych pozwala na pewne uogólnienia. Według Doris Bachmann-Medick kulturoznawstwo staje się obszarem następujących po sobie zwrotów kulturowych, wokół których następuje organizacja dyskursu i autorka wymienia kolejne zwroty, kreśląc kartografię studiów kulturowych. I tak wymienia, jak następuje: interpretive turn, performative turn, reflexive/literary turn, postcolonial turn, translational turn, spatial turn, iconic turn (Bachmann-Medick, 2012). Natomiast Chris Barker w pracy Studia kulturowe. Teoria i praktyka wymienia ponadto somatyczny zwrot studiów kulturowych. Intencją tak rozumianego zwrotu jest „pragnienie zrozumienia sposobu, w jaki ciało staje się przedmiotem kształtowania i dyscyplinowania przez siły społeczne i kulturowe, czyli tego, jak ciało nabywa znaczenia w kulturze współczesnej” (Barker, 2005: 56). 
Przedmiotem analizy w tym szkicu będzie specyfika zwrotu somatycznego, z ukazaniem kilku ważnych kontekstów, ku którym ciąży współczesna refleksja, by rozwinąć ogólną intencję: jak ciało nabywa znaczenia w kulturze współczesnej. Postawiony w tytule problem prowokuje rozważenie wzajemnych związków pomiędzy kulturą późnej nowoczesności a tożsamością ( $\mathrm{z}$ uwzględnieniem zwłaszcza ciała w procesie konstruowania tożsamości). Jak pisze przywoływany na wstępie Chris Barker: „Obserwując rozwój dyskursów władzy dyscyplinarnej na przestrzeni dziejów, można ulokować poszczególne rodzaje «reżimów własnego ja» w konkretnych okolicznościach historycznych i kulturowych. Oznacza to, że różne rodzaje podmiotów są konsekwencją różnych formacji historycznych i społecznych" (Barker, 2005: 262). Tak zarysowany problem zmierza do ukazania subtelnych odcieni znaczeniowych z pola badań nad tożsamością epoki instant. Chciałbym od razu zaznaczyć, iż moja próba nie będzie wyczerpującą prezentacją zagadnienia, a zmierza do naszkicowania problemów wyłaniających się z tak ujętego pola badawczego. Intencją tego tekstu jest prezentacja kontekstów i ukazanie kilku znaczących dyskursów w rozważaniach nad obecnością ciała w kulturze współczesnej. Proponuję, po pierwsze, zarysowanie i zderzenie ze sobą dwóch dominujących perspektyw w badaniach nad cielesnością, mianowicie, wychodząc od rozważań Anthony’ego Giddensa nad tożsamością refleksyjną i ujęcia cielesności w ramach tej koncepcji, zamierzam przybliżyć sposób, w jaki ciało bywa problematyzowane w nurcie paradygmatu konstruktywistycznego oraz, po drugie, zaprezentuję koncepcję i sposób konceptualizowania ciała w podejściu integralnym. Nie ukrywam, że propozycje konstruktywistyczne zestawione z podejściem integralnym ujawniają przeświadczenie autora o korzyściach z przyjęcia tej opozycyjnej perspektywy oraz słabość, jeżeli nie pułapki, podejścia konstruktywizmu kulturowego. Odwołując się do przedstawicieli rozmaitych badań społecznych, próbuję podsumować dominujące tendencje kultury instant poprzez kategorię cielesności. W dalszej części szkicu prezentuję poglądy Kena Wilbera na temat „integralnej praktyki życiowej” jako części jego integralnego podejścia do rozwoju, także poglądy Jona Kabat-Zinna, niestrudzonego propagatora uważności w terapii stresu i depresji, twórcy systemów (MBSR) i (MBCT). Te aspekty „odkrycia uważności”, obecne w zachodnich praktykach, stanowią ważną inspirację w wymienionych polach życia społecznego, stanowią zapowiedź alternatywy zapoczątkowanej przez rewolucję psychologii humanistycznej. Przedmiotem analiz w tym opracowaniu jest system integralnej filozofii, a także sylwetka Kena Wilbera, prawdziwego pioniera współczesnych badań nad naturą rozwoju duchowego, prezentującego rewolucyjne podejście do wzbogacającego rozwoju opartego na matrycy AQAL. Tematy te podejmowałem kilkakrotnie w swoich wcześniejszych pismach, jednak chciałbym przybliżyć środowisku pedagogów profil inte- 
gralnego stanowiska Kena Wilbera, którego pisma wciąż domagają się omówienia, zwłaszcza dlatego że podejście zaprezentowane w idei „integralnej praktyki życiowej” daje szansę na zrównoważony, synergicznie zbalansowany rozwój osobisty nie tylko i wyłącznie pedagogów, ale także ich podopiecznych w kierunku postulatów psychologów humanistycznych, o której Ken Wilber pisze, że jest „psychologią ludzkiego potencjału".

\section{Ciało w projekcie refleksyjnej tożsamości}

We wnikliwym studium Nowoczesność $i$ tożsamość. "Ja” i społeczeństwo w epoce późnej nowoczesności Anthony Giddens przekonująco rozwija paradygmat ponowoczesnej tożsamości w szerokim planie kulturowej transformacji. Tłem dla pogłębionej analizy jest społeczeństwo globalne późnej nowoczesności. Jak zauważa Giddens, na radykalną odrębność społeczeństwa nowoczesnego wpływ ma przede wszystkim niesłychany dynamizm. Pisze: „Nowoczesny świat «ucieka»: nie tylko tempo zmian jest nieporównanie szybsze niż w przypadku jakiegokolwiek wcześniejszego systemu, ale niespotykany jest także zasięg i radykalny wpływ, jaki wywierają na zastane praktyki i zachowania społeczne" (Giddens, 2006: 23). Giddens wyróżnia trzy elementy składające się na to zjawisko: po pierwsze - rozdzielenie czasu i przestrzeni; po drugie - wykorzenianie instytucji społecznych; po trzecie refleksyjność. Wszystkie razem zaważą na wyłonieniu się nowej wykładni pojęcia tożsamość. Dwa ostatnie czynniki warte są krótkiego omówienia. Giddens wyróżnia dwa rodzaje mechanizmów wykorzeniających, a mianowicie: środki symboliczne i systemy eksperckie, które nazywa ogólnie systemami abstrakcyjnymi. Środki symboliczne to środki wymiany o znormalizowanej wartości, na przykład pieniądz. Natomiast systemy eksperckie to ogarniające wszystkie obszary nowoczesnego życia społecznego formy ekspertyzy technicznej, obecnie obejmujące również relacje społeczne i problemy osobowości. Jak zauważa: „Lekarz, doradca i terapeuta są tak samo istotni dla systemów eksperckich nowoczesności jak naukowiec, technik czy inżynier" (Giddens, 2006: 27). Kluczowym pojęciem działania systemów eksperckich w przecięciu ze społecznym życiem jednostek jest zaufanie „które wspiera ograniczoną wiedzę techniczną, jaką ma większość ludzi na temat skodyfikowanych informacji, które rutynowo wpływają na ich życie” (Giddens, 2006: 28). Systemy eksperckie jako mechanizmy wykorzeniające „odrywają życie społeczne od wzorców i ustalonych praktyk” (Giddens, 2006: 29). Trzecim elementem dynamizmu nowoczesnych instytucji jest refleksyjność, która oznacza, że „większa część społecznej aktywności i materialnego stosunku do przyrody jest 
systematycznie poddawana rewizji ze względu na nowo zdobyte wiadomości lub nabytą wiedzę" (Giddens, 2006: 29). Typowa nowoczesna refleksyjność pozwala rewidować każdą wiedzę w obliczu nowych odkryć i teorii, zarazem sama stanowi źródło niepokoju egzystencjalnego ludzi w epoce późnej nowoczesności. Natomiast wykorzeniające działanie systemów eksperckich to według Giddensa „dewaluacja umiejętności w wielu aspektach życia społecznego" (Giddens, 2006: 31).

W porządku posttradycyjnym (to odmienna nazwa społeczeństwa późnonowoczesnego) tożsamość staje się refleksyjnym projektem. Systemy abstrakcyjne okazują się istotne nie tylko i wyłącznie, „dla porządku instytucjonalnego nowoczesności, ale również dla formowania i zachowania ciągłości tożsamości” (Giddens, 2006: 48). Najbardziej znamienne powiązanie systemów abstrakcyjnych i projektu tożsamości refleksyjnej widoczne jest w rozwoju nowych form terapii i doradztwa.

Z ogólnego twierdzenia o tożsamości jako projekcie refleksyjnym Giddens wyprowadza następujące cechy tak rozumianej tożsamości:

1) tożsamość jest projektem refleksyjnym, za który jednostka jest odpowiedzialna (nie jesteśmy tym, czym jesteśmy, ale tym, co z siebie zrobimy);

2) „ja” tworzy trajektorię rozwoju od przeszłości do antycypowanej przyszłości, która jest spójna i wynika z poznawczej świadomości różnych faz przebiegu życia;

3) refleksyjność tożsamości jest ciągła i wszechogarniająca i polega na nieustannym powracaniu do pytania: „Jak mogę wykorzystać ten moment, żeby się zmienić?";

4) tożsamość jako spójna całość zakłada narrację (narracja „ja” staje się jawna); prowadzenie dziennika i przepracowywanie autobiografii to główne zalecenia mające pomóc w utrzymaniu zintegrowanego poczucia „ja”;

5) samorealizacja zakłada panowanie nad czasem jako sposób kontrolowania danego jednostce życia;

6) refleksyjność tożsamości rozciąga się na ciało;

7) samorealizacja jest rozumiana jako równowaga między szansą a ryzykiem; świat wypełnia się możliwymi, w sensie eksperymentalnych gier, jakie może teraz rozpocząć jednostka, sposobami bycia i działania;

8) moralną osią samorealizacji jest autentyczność polegająca na „byciu szczerym z samym sobą";

9) przebieg życia jest postrzegany jako seria „przejść”;

10) rozwój „ja” przebiega samozwrotnie; zintegrowana tożsamość, osiągnięcie autentycznego „ja”, wynika z integracji doświadczeń życiowych w narracji własnego rozwoju (Giddens, 2006: 105-111). 
Późnonowoczesny pejzaż egzystencjalny stawia przed człowiekiem konieczność wyboru spośród rozmaitych form tworzenia tożsamości i praktyk samorealizacji, ale jednocześnie nie udziela wskazówek, które z nich należy wybrać. Według Giddensa z pomocą przychodzi pojęcie stylu życia, definiowanego „jako mniej lub bardziej zintegrowany zespół praktyk, które podejmuje jednostka nie tylko dlatego, że są użyteczne, ale także dlatego, że nadają materialny kształt poszczególnym narracjom tożsamościowym" (Giddens, 2006: 113).

Jak zauważa Giddens: „Im bardziej posttradycyjny jest porządek, w którym porusza się jednostka, tym silniej styl życia dotyczy samego rdzenia tożsamości, jej kształtowania i przekształcania” (Giddens, 2006: 113). Istotą stylu życia jest wytworzenie całościowego i uporządkowanego wzoru postaw codziennych i nawyków, ważnych z punktu widzenia wytworzenia poczucia bezpieczeństwa ontologicznego. Obok pluralizacji stylów życia w epoce późnej nowoczesności pojawia się pojęcie planów życiowych, które, według Giddensa, „są treścią refleksyjnie zorganizowanej trajektorii tożsamości” (Giddens, 2006: 118).

W warunkach późnowoczesnych, zauważa Giddens,

narracja tożsamościowa w ramach refleksyjnego projektu jest z natury krucha. Rezygnacja z konkretnej tożsamości może dostarczać konkretnych korzyści psychicznych, ale jest też z pewnością ciężarem. Jednostka jest zmuszona sama tworzyć i przebudowywać swoją tożsamość ze względu na zmienne doświadczenia życia codziennego i skłonność nowoczesnych instytucji do fragmentaryzacji tożsamości jednostki. (Giddens, 2006: 254)

Pora wreszcie przedstawić zebrane analizy Giddensa na temat roli i znaczenia ciała w refleksyjnym projekcie tożsamości. Jak zauważył Giddens, ciało jest „układem działania, źródłem praktyk, którego czynne zaangażowanie w codzienne interakcje jest konieczne do zachowania spójnego poczucia własnej tożsamości” (Giddens, 2006: 137). Według niego pozwala to wyróżnić podstawowe aspekty cielesności: wygląd ciała, sposób bycia, zmysłowość ciała, reżimy cielesne. Epoka późnej nowoczesności zakłada, że w procesie konstruowania tożsamości aktywną rolę odgrywa aktor społeczny. Jest to także widoczne w odniesieniu do ciała. Jak pisze Giddens: „Zasada czynnego konstruowania tożsamości całkiem wprost dotyczy także ciała. Związane bezpośrednio z wzorami zmysłowości reżimy, jakim poddawane jest ciało, są podstawowym mechanizmem kultywacji, a wręcz kreacji ciała, na której koncentruje się instytucjonalna refleksyjność nowoczesności” (Giddens 2006: 139). Omawiając interesujące nas zagadnienie cielesności, Giddens zadaje podstawowe pytanie: „Jak rozumieć twierdzenie, że ciało stało się częścią refleksyjności nowoczesności?" (Giddens, 2006: 142). Odpowiedź jest następująca: „Właściwe epoce rozwiniętej nowoczesności reżimy, którym poddawane jest ciało, i organizacja doświadczenia zmy- 
słowego są przedmiotem ciągłej refleksyjnej uwagi ze względu na wielość możliwych wyborów. Zarówno planowanie, jak i wybór jakiegoś stylu życia wiążą się (z zasady) z poddawaniem ciała pewnym reżimom" (Giddens, 2006: 142). Giddens wiąże to zjawisko w problemem występowania często sprzecznych programów „ćwiczenia ciała" zawartych w tekstach poradników, które zwrotnie stosujemy na sobie, ale jak powiada: „stajemy się odpowiedzialni za projekt własnego ciała (...), w pewnym sensie jesteśmy zmuszeni je projektować, tym bardziej, im bardziej posttradycyjne są warunki społeczne, w których żyjemy" (Giddens, 2006: 142).

\section{Ciało w perspektywie konstruktywizmu}

Jak pisze Zbyszko Melosik, powołując się na Zygmunta Baumana: „Przez długi okres nauki społeczne próbowały dowiedzieć się jak najwięcej - aby użyć sformułowania Z. Baumana - «o człowieku utkanym z przędzy myśli i uczuć: o człowieku bezcielesnym». Ciało pozostawało domeną biologów, jak gdyby nie było ono w żaden sposób kształtowane przez społeczeństwo i wrażliwe na jego przemiany" (Melosik, 2010: 9). Melosik jednak uważa, że problem cielesności stanowić może wyzwanie dla analityków kultury, gdyż „doświadczenie jednostki jest w dużym stopniu ucieleśnione. Społeczna historia człowieka jest także historią jego ciała, a historia ciała z kolei ma swoje wymiary społeczne" (Melosik, 2010: 9). Autor problematykę ciała ściśle wiąże z kategoriami kobiecości, męskości oraz seksualności. Jak dowodzi, czasy ponowoczesne kwestionują podejścia esencjalne i naturalne w kwestii rozumienia cielesności. Wraz z zakwestionowaniem esencjalnej wykładni człowieczeństwa ponowoczesność uznaje, że ,jego [człowieka - moje J.M.] zakres określony jest zawsze przez praktyki społeczne definiujące, co oznacza być człowiekiem” (Melosik, 2010: 10). Zgodnie z tym przekonaniem powiada Melosik: „biologiczna kobieta i biologiczny mężczyzna stają się społecznymi przedstawicielami tych płci, jeśli egzemplifikują społeczne (zmienne w czasie i pełne sprzeczności) znaczenia, które wyznaczają kobiecość i męskość w danym społeczeństwie” (Melosik, 2010: 11). Jak zauważył, ciało „staje się tekstem, w który wpisywane są różnorodne konfiguracje społecznie konstruowanych znaczeń męskości i kobiecości” (Melosik, 2010: 11). Generalny wniosek dotyczący ciała w tej perspektywie może zostać sformułowany następująco:

Odczytywanie społecznych znaczeń ciała, wpisywanych w nie kształtów i konturów, kolorów oraz różnorodnych symboli dokonuje się w życiu codziennym nieustannie. W kulturze współczesnej (re)prezentowane są przy tym różne dyskursy ciała, które prowadzą ze sobą walkę o uzyskanie statusu „ciała uniwersalnego” (idealnego czy „obowiązującego”, które wszyscy powinni ucieleśniać). (Melosik, 2010: 11) 
Jak zauważa Melosik, a należy potraktować to przekonanie jako generalne nastawienie badaczy z nurtu konstruktywizmu społecznego,

Nie ma ciała „naturalnego” - jest ono zawsze definiowane przez kulturowe i społeczne procesy. W trakcie nich (re)konstruowana jest „prawdziwa” wiedza o ciele. Społeczna presja wywierana na jednostki powoduje, że wiedza ta jest przez nie akceptowana i ucieleśniana w ciałach. Wiedza dotycząca tego, jakie ciało ma być (aby było podziwiane i pożądane, a przede wszystkim po prostu „normalne”), ma charakter normatywny i dyscyplinujący. (Melosik 2010: 13)

Podobne w istocie stanowisko zajmuje Agnieszka Gromkowska w tekście Kobieta epoki wiktoriańskiej: społeczne konstruowanie ciała i tożsamości:

Kobieta i kobiecość stanowią historyczne, społeczne i kulturowe konstrukcje. Kobieta jest kobietą w znaczeniu biologicznym czy fizjologicznym (rodzi się jako kobieta), jednak dopiero socjalizacja sprawia, iż staje się kobietą jako jednostką społeczną. Jest konstruowana poprzez obowiązujące w danej epoce znaczenia kobiecości. Jeśli zaakceptuje je i ucieleśni je w sposób odpowiedni, wówczas jej kobiecość uznana zostaje za „społecznie adekwatną”. (Gromkowska 2000: 59)

Przywołam jeszcze raz Melosika, gdy pisze tak: „Sukces jednostki w sferze stawania się kobietą czy mężczyzną zależy przy tym także od tego, czy jej predyspozycje genetyczne nakładają się na oczekiwania społeczne (doskonale widać to na przykładzie obowiązującego obecnie „ideału szczupłego ciała” kobiety, który jest osiągany tylko przez nieliczne z nich bez wysiłku; wiele kobiet prowadzi beznadziejną walkę ze swoją biologią w celu jego uzyskania)" (Melosik, 2010: 11). W tym miejscu warto przytoczyć uwagę Bauera: „Podmiot zostaje tu uwikłany w niebezpieczeństwo «wciągnięcia» przez wir wpływów społecznych, wymagań i narzuconej tożsamości” (Bauer, 2004: 13).

Szczególnym przypadkiem konstruktywistycznego podejścia do kwestii ciała jest opisywana w tekście Małgorzaty Boguni-Borowskiej Ekstremalne metamorfozy - projekt idealnego człowieka i perfekcyjnego życia w ponowoczesnym świecie kultura ekstremalnych metamorfoz (Bogunia-Borowska, 2006). Autorka wiąże ten ruch z typowym dla kultury konsumenckiej nastawieniem na kreatywność, konkurencyjność, indywidualizm, przyjemność oraz młodość. Jak pisze:

Kultura konsumpcyjna coraz bardziej się upowszechnia, co oznacza, że jednostki niemal automatycznie wskazany zestaw cech uznają za jedyny obowiązujący i właściwy. W konsekwencji można postawić tezę, że weszliśmy w kolejny, bardzo wyrafinowany etap rozwoju kultury konsumenckiej. Ta faza przemian kulturowych i społecznych jest na tyle wyrazista 
i klarowna, że można ją opisywać jako osobne zjawisko, znajdujące wyraz w istotnych procesach dotyczących zarówno jednostek, jak i ich otoczenia, jednym słowem życia codziennego w wielu jego przejawach. Proponuję, abyśmy określili ją mianem kultury ekstremalnych metamorfoz lub kultury makeover. (Bogunia-Borowska, 2006: 69)

Co wyróżnia kulturę ekstremalnych metamorfoz?

Autorka przybliża nam jej specyfikę w następujący sposób: „Kultura metamorfoz polega na dokonywaniu radykalnych, odważnych, a nawet niejednokrotnie ryzykownych transformacji bardzo różnych sfer i wymiarów ludzkiej egzystencji” (Bogunia-Borowska, 2006: 69), oraz „Idea makeover rozpoczęła się od zmian wizualnych aspektów ciała. Obecnie obejmuje wszelkie wizualne i estetyczne formy życia człowieka" (Bogunia-Borowska, 2006: 71). Autorka szeroko omawia cechy kultury metamorfoz, nas interesuje tutaj jej aspekt związany z ideą doskonalenia oraz wykształceniem wraz z nią kulturą ekspertów i specjalistów. Jak pisze: „Kultura metamorfoz to kultura doskonalenia, ale już nie samodoskonalenia, ale doskonalenia przy pomocy innych, którzy wiedzą, jak tego w najkrótszym czasie dokonać" (Bogunia-Borowska, 2006: 71). Jak wynika z przytoczonych rozważań autorki, kulturę metamorfoz można traktować jako archetypowe wcielenie kultury instant, wszak jedną z jej cech jest zapośredniczenie samorealizacji człowieka poprzez kulturę ekspertów i różnego rodzaju specjalistów od zmiany i rozwoju oraz natychmiastowe rezultaty takich zabiegów.

Autorka przytaczanego tekstu zauważa, że: „Znaczenie specjalistów, czyli dietetyków, chirurgów plastycznych, stomatologów, ortodontów, wizażystów, stylistów, architektów, trenerów fitness, dekoratorów, ogrodników, organizatorów przyjęć, kreatorów mody, psychologów jest ogromne, gdyż bez ich pomocy żadna radykalna metamorfoza nie miałaby szans na przeprowadzenie w krótkim czasie" (Bogunia-Borowska, 2006: 70).

Podstawową siłę perswazyjną we wzmacnianiu oddziaływania na szybkie transformacje stanowić może reklama, poddająca jednostkom sposób na stałe bycie trendy i na czasie, pozostaje jednak pytanie „czy poddanie się woli i wizji innych ludzi, nawet uchodzących w kulturze za ekspertów, jest sposobem na autentyczny i prawdziwy rozwój jednostki w społeczeństwie" (Bogunia-Borowska, 2006: 73). Autorka widzi w tym wielkie zagrożenie na utratę wolności, gdy pisze: „Owo anektowanie ludzkiej tożsamości i kreowanie perfekcyjnego człowieka i jego idealnego życia prowadzi do sprawowania nad jednostką władzy. Odbierając jej możliwość kreacji własnej tożsamości, w rzeczywistości produkuje się sztuczny twór, który staje się klonem innych takich samych jak on "produktów» eksperckiej fantazji” (Bogunia-Borowska, 2006: 75). 


\section{Ciało w perspekływie integralnej - wprowadzenie}

Owszem, można zgodzić się z Kenem Wilberem, który nazywa ponowoczesność kulturą płaskiej Ziemi i zgodnie z tym w zapomnienie odeszły wszelkie rozważania odwołujące się do wartości, a o wartościach innych niż hedonistyczne w naszej epoce trudno już rozmawiać. Nastąpiła wraz z tym degradacja dobrych obyczajów i obniżenie standardów moralnych, rozmycie granic i zanik poczucia sacrum, zatracenie moralności i zagubienie człowieczeństwa. Krótko mówiąc: brutalizacja i barbarzyństwo kultury. Mam jednak pewność, że nie wszyscy pogodzili się z tym stanowiskiem.

W kulturze współczesnej narasta jednak silne przekonanie i praktyki podważające zarysowane wyżej tendencje. To zaledwie sygnał, ale w ostatnich dwóch dekadach mamy jakby renesans pewnych istotnych zagadnień humanistycznych. Istnieje obecnie wiele szkół myślenia, które, idąc pod prąd obiegowych prawd, wciąż zachowują resztki humanizmu. W psychologii na przykład pojawiło się pojęcie inteligencji emocjonalnej, w której upatrywać można powrotu do zapomnianych, wypartych treści humanistycznych.

Jak zauważa John Lechte w pracy Panorama współczesnej myśli humanistycznej. Od strukturalizmu do postmodernizmu: „Można oczywiście spierać się o to, co powinno się (dzisiaj) znaleźć w kanonie filozoficznym (Zachodu), nie ulega jednak wątpliwości, że kanon ten nadal wywiera na nas przemożny wpływ” (Lechte, 1998). Zdezaktualizowały się mapy starego świata, autorytety wydają się zagrożone, pokomplikowały się nasze tożsamości. Kultura współczesna dotknięta jest chorobą permanentnego kryzysu. Świat społeczny skomplikował się na tyle, że fundamentalne dla naszej kultury wartości stanęły przed groźbą anihilacji. Radykalna krytyka podstaw naszej egzystencji w wymiarze zbiorowym tchnęła w nasze życie niczym niepohamowany sceptycyzm. Wkradł się on w wymiar indywidualnego życia, czyniąc głębokie spustoszenie w warstwie etycznej. Niemodne stało się w takim klimacie odwoływanie się do wartości uniwersalnych, a życie zwykłego uczestnika kulturowej gry toczy nieodwołalnie nihilizm. I tak, w klimacie zmiany, w tym pejzażu pojawiła się oryginalna myśl psychologiczna, wpisując się w bogatą tradycję europejskiej kontrkultury. Psychologia humanistyczna na starcie więc trafiła na niezbyt przychylne środowisko kulturowe, wydawało się bowiem, że wraz z upadkiem wszelkich, mocnych fundamentów naszej kulturowej tożsamości w odstawkę odeszło myślenie odwołujące się do wszelkich wartości. Posądzana przez wielu o naiwność czy idealizm psychologia humanistyczna być może wpłynęła na przetrwanie podstawowych ludzkich wartości, takich jak: sens życia, odpowiedzialność i wolność duchowa. Jak się wydaje, w takim milieu kulturowym 
jest to przedsięwzięcie cechujące się wyjątkową odwagą intelektualną. Kwestie duchowe dopominają się obecności w dyskursie publicznym, gdyż w epoce instant zanika rozróżnienie na sferę publiczną i prywatną. Wyjałowiona kultura płaskiej Ziemi (Wilber) domaga się wzmocnienia refleksji aksjologicznej, by dać zadość powołaniu człowieka do pełnego, integralnego rozwoju.

Intencją projektu integralnego jest docieranie do treści wypieranych, pomijanych, nieznanych, zarazem ukazanie nurtów, trendów, ruchów kulturowych jako składowych niezmiernego ożywienia społecznego na duchowym rynku. Zaszczepienie buddyzmu na gruncie zachodnim powoduje wiele zaskakujących zmian w świadomości ludzkiej, ale również przemieszczenie dyskursu społecznego. Dowodem na to jest chociażby instytucja „integralnych praktyk życiowych” wyprowadzana $\mathrm{z}$ dorobku amerykańskiego myśliciela Kena Wilbera. Jednak jeszcze raz powtórzę, zadaniem zaangażowanej krytyki jest stawianie pytań tak, by przezwyciężyć impas, w jakim znalazła się humanistyka współczesna po okresie zbyt wybujałego wątpienia. Owszem, można zgodzić się z diagnozą kultury ponowoczesnej Kena Wilbera, nazywającego ponowoczesność kulturą płaskiej Ziemi (zero głębi; jedynie powierzchnia), która, mówiąc oględnie, nie sprzyja rozważaniom o wartościach (a więc o hierarchiach czy poziomach urzeczywistnienia), i w impecie adiaforycznych tendencji (Bauman 1996) wyjaławia ją do cna, siejąc spustoszenie etyczne wśród jej mieszkańców, którzy poruszają się bez wewnętrznej busoli i doświadczają boleśnie upadku wiary w sens życia (Giddens, 2006).

Tak oto rysuje się pesymistyczna perspektywa postmodernizmu, w której dominującym nastrojem wśród badaczy świata kultury wydaje się zwątpienie $\mathrm{w}$ sens tworzenia jakichkolwiek konstrukcji i ostateczne przekroczenie rozbicia naukowego dyskursu. Wydawać się też może, że wszelkie próby odchodzenia od dominującego idiomu postmodernistycznej narracji w filozofii skazane są na niepowodzenie albo narażone bywają na zarzut tworzenia nowych logocentrycznych i imperialnych ram dla naszego myślenia. Wydaje się również, że wszelka propozycja wykraczająca poza wspomniane dylematy postmodernistycznej filozofii kultury nie ma szans na zaistnienie w świecie rozparcelowanego dyskursu na wiązki, niespójne małe narracje. Tymczasem od lat co najmniej kilkunastu obecna jest wizja integralna Kena Wilbera, amerykańskiego psychologa transpersonalnego i filozofa.

Kultura ponowoczesna, a więc kilku ostatnich dekad XX wieku, to epoka zaniku wszelkich wartości uniwersalnych. Obecnie to zysk stał się dominującym napędem ludzi. W zapomnienie poszły wartości inne niż hedonistyczne. Kulturowy Disneyland oferuje nam zabawę jako podstawową formę uczestnictwa w kulturowej grze. Przyspieszenie i wymieszanie wszystkiego na straganie światowym to 
oznaka naszych czasów. Czasy obecne nie sprzyjają głębszej refleksji, dominuje powierzchowny odbiór oraz możliwość nieograniczonego dostępu do ofert tej kultury instant. Przyświeca nam pomysł otrzymania wszystkiego od razu i w nieograniczonej ilości. Coraz trudniej w takich warunkach zachować równowagę i celność wyboru. Gdy anything goes to w życiu brakuje priorytetów. Czasy ponowoczesne ogarnęła wszechogarniająca ambiwalencja. Niepewność i upadek wszelkich oczywistości to kultura nieustannej zmiany i płynności. Coraz trudniej zachować dzisiaj, w czasach nieustannego przepracowania zdrowie emocjonalne i zintegrowaną postawę życiową. Wydaje się, że rywalizacja zastąpiła ludzką solidarność. Bogaci żyją w bogactwie, a biedni w biedzie. Świat rozpadł się na strefy lokalne: z jednej strony powstała już cywilizacja globalna (np. Internet), z drugiej następuje powrót do lokalnych tradycji. Wydaje się, że czasy ponowoczesne nie sprzyjają moralnej refleksji.

Na zakończenie tych rozproszonych rozważań o humanizmie epoki ponowoczesnej chcę się pokusić o krótkie uogólnienia. Jak wygląda duchowość człowieka początku XXI wieku, przeciętnego mieszkańca globalnej wioski? W klimacie globalizacji nasza duchowość też przeszła ogromne przeobrażenia. Po raz pierwszy w historii Wschód spotkał się z Zachodem. Obydwie tradycje wpływają dzisiaj na siebie wzajemnie. Pragmatyczna cywilizacja Zachodu spotyka się z ezoterycznym Wschodem. Mamy dzisiaj dostęp do zasobów, wszelkich zasobów duchowych. W obiegu ogólnoświatowym znalazły się wszelkie obecne na rynku duchowym idee. Na Zachodzie pojawiły się idee i praktyki, które przez długie stulecia stawały się dostępne jedynie wybranym. Natomiast na Wschodzie zadomowiła się tradycja naukowa Zachodu. To zdecydowanie fenomen XX wieku. Ludzie Zachodu szukają dzisiaj inspiracji na Wschodzie. Wschodnie idee przeniknęły już do codziennego dyskursu człowieka Zachodu. Wystarczy otworzyć jakikolwiek ilustrowany magazyn czy pooglądać telewizję! Wypada dzisiaj być TRENDY, a pojęcia czy idee tych rdzennych tradycji weszły już do codziennej konwersacji społecznej. W drugiej połowie XX wieku pojawił się na rynku duchowym New Age. Era Wodnika to epoka całkowitego wymieszania się tradycji i praktyk przypisanych wcześniej i strzeżonych przez wspólnoty lokalne. W dobie nowych mediów wszelkie istniejące wcześniej praktyki duchowe stały się dobrem i towarem ogólnoświatowym. Nic, absolutnie nic, co wyraża ludzką tęsknotę za rozwojem duchowym, nie jest już tajemnicą.

Tak więc duchowość człowieka tuż po przełomie milenijnym nie ma jednolitego oblicza. Ważne jest jednak, aby czerpać z tradycji, tak by świat mógł się harmonijnie rozwijać. Niektóre mody duchowe niedługo przeminą, ale ważne jest, aby strzec tradycji wszelkich rdzennych praktyk duchowych. 


\section{Problematyka ciała w wybranych systemach terapeutycznych}

Problematyka ciała nie ominęła również nurtów psychoterapeutycznych znajdując tutaj znakomite artykulacje. Coraz powszechniejszy staje się w świecie Zachodu problem wzajemnych relacji pomiędzy ciałem a umysłem. Pojawiło się więc wiele systemów terapeutycznych, dla których dopiero obecność ciała i cielesności stanowi podstawę naprawdę zintegrowanego (nieredukcjonistycznego) modelu tożsamości.

Zdaniem Alexandra Lowena zdrowa tożsamość skrywa się całkowicie w „ja” cielesnym. Lowen poświęcił wiele swoich prac (co ważne, od niedawna również wydawanych w Polsce), argumentując za potrzebą wsłuchiwania się w potrzeby ciała, które jest naszym naturalnym wyposażeniem, a którego ignorowanie, czy często wyparcie prowadzi do poważnych zaburzeń tożsamościowych. Tematyka ta znalazła swój wyraz w tytule jednej z prac Lowena, a mianowicie pracy Zdrada ciała. Śledzi w niej Lowen procesy braku podmiotowej identyfikacji z własnym ciałem, co prowadzi wprost do patologicznego modelu funkcjonowania i zaburzonego poczucia tożsamości. Oczywiście omawiane przeze mnie terapeutyczne konteksty cielesności to obszar intensywnych badań podejmowanych w ramach wielu odrębnych systemów terapeutycznych, jednak chciałbym przybliżyć zaledwie dwa z nich, jako przyczynek do bardziej wyczerpujących ujęć problemu.

Dla wielu z nas książka Świadoma droga przez depresję może okazać się zaskakującym spotkaniem z praktykowaną na ścieżce medytacji uważnością. Choć autorzy zajęli się w niej coraz bardziej alarmującym problemem społecznym, jakim jest depresja, dręcząca wiele osób i rujnująca życie wielu z nich, jednak przesłanie tej pracy nie ogranicza się wyłącznie do anatomii tej choroby. Wychodząc bowiem z doświadczeń medytacji (w tym szczególnie uważności), oferują wielu poszukującym osobom, przygniecionym często przez rozmaite zdarzenia życiowe lub obciążonych nadmiernym stresem życia, niespotykaną na Zachodzie szansę zetknięcia się z całkowitą alternatywą wobec dominujących praktyk terapeutycznych. Oparta na treningu uważności oraz zdobyczach terapii poznawczej propozycja MBCT [Mindfulness-Based Cognitive Therapy] jest pracą odkrywczą i dla wielu czytelników z pewnością okaże się ostoją nadziei w świecie nadmiernego ryzyka. Program terapeutyczny tam zawarty nawiązuje wprost do doświadczeń kliniki redukcji stresu w oparciu o uważność założonej w roku 1979 przez Jona Kabat-Zinna. Podobnie tutaj autorzy proponują 8-tygodniowy trening uważności, w trakcie którego uczestnicy terapii wypracowują własny styl treningu uważności. Wiele z zaproponowanych tam ćwiczeń medytacyjnych zmierza do zakorzenie- 
nia świadomości w trybie bycia, czyli przekroczenia trybu działania nieskutecznego, jak się okazuje, w zapobieganiu skutkom wyniszczających zdarzeń życiowych. Odkrycie uważności to z jednej strony próba podzielenia się dobroczynnym doświadczeniem wyniesionym z praktyki uważności oraz jednocześnie odkrycie we własnym życiu wagi uważności jako nowego stylu życia w procesie osobistej transformacji i odkrywaniu siebie. Tym samym propozycja ta wpisuje się $\mathrm{w}$ typowy nurt kultury współczesnej, w której występuje wzmożone zainteresowanie sprawą osobistego rozwoju, a kultura terapeutyczna zyskuje dzięki tej propozycji humanistyczne oblicze. Istnieje oczywiście szeroka gama takich eksperymentów rozwojowych, można tu także wspomnieć o pomyśle integralnej praktyki życiowej Kena Wilbera.

Wracając do pomysłu terapii opartej na uważności: bazuje ona na zdobyczach psychologii poznawczej, dzięki której odkryto wagę sprzężenia zwrotnego pomiędzy umysłem i ciałem. Dlatego wiele miejsca poświęca się tutaj na ukazanie i praktykowanie uważności, także ciała, i docieranie do mądrości doświadczenia zapisanego w ciele. Dla zdesperowanych ludzi, nieskutecznie szukających rozwiązania problemów jedynie dzięki myśleniu, otwarcie bramy ciała i doznań fizycznych może mieć całkowicie wyzwalający charakter. Jeszcze innym aspektem jest również waga emocji w zdrowym funkcjonowaniu. Dzięki praktyce uważności odkrywamy, po pierwsze, ciało jako źródło mądrości oraz wagę emocji po procesie zdrowienia. Uczymy się przede wszystkim postawy nieosądzającej świadomości oraz kultury psychologicznej i wglądu w naturę myślenia i odczuwania. Tak więc zarysowana w projekcie MBCT praktyka uważności to także odkrycie na nowo możliwości tkwiących w naszym naturalnym potencjale człowieczeństwa. Jest to propozycja z pewnością optymistyczna, o czym świadczą dane z badań nad malejącym ryzykiem nawrotów depresji u pacjentów po kursie uważności.

Trening uważności uczy także nowej postawy i jest to na pewno ważny walor edukacyjny tego modelu. Jeśli nie podejmujemy ryzyka, to tak naprawdę okradamy się z szansy na doświadczanie zmiany oraz nie mamy wiedzy oraz uczucia wzrastania i uczenia się poprzez doświadczanie życia. Aktywność jest najważniejsza, a także nieunikanie kontaktu ze sobą $\mathrm{w}$ procesie transformacji. Jak możemy się rozwijać, gdy jesteśmy bierni i tkwimy w powtarzalnych, schematycznych zachowaniach?

Innym systemem terapeutycznym, w którym autorzy odnoszą się do ciała, jest koncepcja MBB (Mind Body Bridging) autorstwa Stanleya i Carolyn Blocków. Twórcy tego modelu opierają swoją koncepcję na technikach dostrojenia i mapowania umysłu-ciała. Zdaniem autorów techniki dostrojenia to nasz układ tożsamości prowadzi do poczucia bycia odrębną jednostką i utraty kontaktu ze Źródłem. Jak piszą: „Kiedy układ tożsamości jest nadaktywny, ogranicza twoją 
świadomość, wywołuje strach, niszczy harmonię oraz równowagę umysłu i ciała” (Block, Block, 2011: 26). Zdaniem autorów „podstawą istnienia układu tożsamości jest szczególny rodzaj myśli zwanych wymogami” (Block, Block, 2011: 27). Zdaniem twórców metody dostrajania „Kiedy wprawisz układ tożsamości w stan spoczynku, to znaczy, gdy rozpoznasz wymogi oraz wewnętrzne opowieści i nie pozwolisz się im prowadzić, do głosu dojdzie twoja naturalnie i swobodnie funkcjonująca jaźń” (Block, Block, 2011: 33). Jak piszą: „Ten układ nie pozwala ci doświadczyć ani wyrazić tego, kim naprawdę jesteś" (Block, Block, 2011: 35). Układ tożsamości sprawia, że jesteśmy w stanie odrętwienia. Autorzy przywołują słowa jednego z uczestników warsztatów MBB: „I tak żyję swoim życiem (...), ale nie doświadczam pełni swojej prawdziwej jaźni, bo mój układ tożsamości oderwał mnie od mojego ciała, przytłumił moje zmysły. Odciął mnie od tego, kim naprawdę jestem" (Block, Block, 2011: 36). Dostrojenie sprawia, że funkcjonujesz w naturalny sposób. Składa się z dwóch kroków: po pierwsze - praktyka bycia świadomym, która wprawia układ tożsamości w stan spoczynku. Jak wyjaśniają, „dzięki byciu świadomym wracasz do chwili obecnej i uświadamiasz sobie obrazy, dźwięki, doznania fizyczne i przepływające myśli (...). Bycie świadomym układu tożsamości jest wszystkim, czego potrzebujesz, by wprowadzić go w stan spoczynku" (Block, Block, 2011: 39); po drugie - na tym etapie dostrojenia chodzi o „zaprzyjaźnienie się z układem tożsamości, co oznacza rozpoznawanie i rozumienie jego wymogów oraz tego, w jaki sposób ograniczają one twoje życie” (Block, Block, 2011: 39). Punktem centralnym metody dostrajania się jest procedura mapowania umysłu. Pozwala ono zlokalizować własny układ tożsamości, wtedy także, „gdy wyciągniesz układ tożsamości na światło dzienne, obejmiesz go swoją świadomością, będziesz w stanie wyjść poza ograniczające cię myśli i uzyskać szeroką perspektywę" (Block, Block, 2011: 49). Co równie istotne, układ tożsamości odcina nas również od ciała. Autorzy proponowanego modelu terapeutycznego proponują proste ćwiczenia, by odzyskać kontakt $\mathrm{z}$ ciałem.

\section{Ciało w perspektywie integralnej}

Celem tego tekstu jest zarazem ukazanie sylwetki Kena Wilbera, amerykańskiego pisarza, psychologa i filozofa transpersonalnego szerokiemu gronu odbiorców. Ken Wilber to światowej sławy pisarz, jeden z pionierów i twórca oryginalnego podejścia do rozwoju osobistego oraz systemowego ujęcia warunków transformacji kultury zachodniej do stadium integralnego. Autor wielu prac z zakresu duchowości, psychologii integralnej oraz twórca inspirującego modelu rozwoju 
osobistego w postaci integralnej praktyki życiowej. Ken Wilber należy do grona najwybitniejszych współczesnych propagatorów idei zbliżenia Wschodu z Zachodem. Obok innego amerykańskiego adepta buddyzmu, Jona Kabat-Zinna, należy do najwybitniejszych przedstawicieli i autorytetów wprowadzających idee uważności i doświadczenia medytacyjne do głównego nurtu współczesnej psychologii i psychoterapii. Choć Wilber jest autorytetem w kwestiach rozwoju duchowego, pozostaje w Polsce wciąż autorem słabo znanym, pomijanym do niedawna w badaniach nauk społecznych. Sam zorganizował prężne ośrodki rozwijające filozofię integralną zwane instytutami integralnymi. Inną kwestią pozostaje odbiór jego twórczości sprawiający trudność również badaczom jego dorobku, o zwykłym czytelniku nie wspominając, nie wyłącznie z powodu ogromu dzieł jego autorstwa, ale przede wszystkim z zawiłości spraw, które w swojej twórczości porusza. Niezbędne zatem wydaje mi się wprowadzenie w tematykę integralnej filozofii, zawiłości i genezę używanej przez Wilbera terminologii, a także wskazanie doniosłości i aktualności jego twórczości na dyskursywnej mapie badań kulturowych i antropologicznych. Pojawiają się co prawda prace omawiające jego dorobek, czego dobrym przykładem są publikacje Marzanny Kielar, eksplorujące edukacyjny potencjał myśli Wilbera, jednak warto zarazem podkreślić, że kwestie rozwoju integralnego pieczętujące jego dorobek w dziedzinie ewolucji osobistej oraz kulturowego przełomu pozostają jednak jak dotąd niezbyt popularne. Dla autora sprawą niezwykle doniosłą jest wprowadzenie do dyskursu edukacyjnego rozważań Wilbera wokół kwestii integralnego rozwoju, a przede wszystkim nieznanej polskiemu odbiorcy pracy Integral Life Practice. W kilku swoich ostatnich szkicach powołuję się na ideę integralnego rozwoju, jednak rozumiem, że wymaga ona dokładniejszej prezentacji, tak, aby idea wyrosła na gruncie osobistej praktyki medytacyjnej Wilbera i grona propagatorów znalazła pole zastosowań w świecie naszych społecznych zmagań, wzbogacając perspektywę rozwoju osobistego o istotny punkt odniesienia. Myślę, że Ken Wilber, obok Jona Kabat-Zinna, należy do najbardziej interesujących autorów inspirujących się myślą Wschodu. Oczywiście można także wspomnieć twórcze podejście Daniela Golemana w badaniach nad inteligencją emocjonalną, jako autora również eksplorującego doświadczenia medytacyjne. Tekst ten chciałbym potraktować jako wstęp do prezentacji stanowiska Kena Wilbera oraz prześledzenie literatury na temat twórczego wykorzystania doświadczeń medytacyjnych przez badaczy zachodnich.

Pisma Wilbera odegrały nieocenioną rolę w absorpcji filozofii wieczystej. Nieprzypadkowo zalicza się Wilbera do grona propagatorów psychologii transpersonalnej, a więc dziedziny myśli, w której rozpatruje się zagadnienia szeroko rozumianej duchowości. Popularność zawdzięcza w pewnym stopniu uformowaniu się 
specjalnego typu odbiorcy duchowości w epoce New Age, w której autorzy prześcigają się w pokazywaniu duchowości na wiele sposobów. Sam siebie uważa za pandita, a więc nauczyciela, który nie ma uczniów - to pozycja skromnego outsidera. Pisarstwu Wilbera patronuje misja dokonania syntezy dwóch kultur: wschodniej i zachodniej, by w dojrzałej postaci swojej wizji integralnej kultury troski nie stracić niczego z dorobku każdej z osobna. Nie można bowiem zgodzić się na ignorowanie dorobku medytacji przez Zachód, tak jak nie można zgodzić się na ignorowanie dorobku naukowego przez Wschód. Wilber więc pragnie zbudować syntezę w taki sposób, by dać zadość każdej w swojej domenie. Nowoczesna duchowość nie może w równym stopniu obejść się bez nauk Buddy, jak Freuda. Wydane dotąd prace (dotyczy to polskich przekładów jego prac) świadczą dobitnie, jak karkołomne to zadanie, ale jednocześnie widać precyzję i biegłość poruszania tematów z każdej ze wspomnianych domen wiedzy. Każda z jego książek oświetla kolejny kontekst w oswajaniu zagmatwanych ścieżek ducha. Ten niezwykle płodny `pisarz zręcznie przedstawia i przyswaja w swoich pismach własne integralne stanowisko.

Jak napisałem, głównym motorem jego pisarstwa jest chęć usystematyzowania dokonań na polu badań nad świadomością. W tradycji Zachodu rola ta zarezerwowana jest dla psychologów bądź psychoterapeutów. Ken Wilber nie ma wykształcenia psychologicznego, ale dokonania jego dorównują pracom takich teoretyków i wizjonerów, jak chociażby sam Zygmunt Freud. Pisma Wilbera urzekają prostotą i klarownością wglądu w najbardziej skomplikowane zagadnienia świadomości. Już od pierwszych jego prac daje się zauważyć wielką odwagę w przełamywaniu dominujących sposobów dyskursywizacji tego fenomenu. Jak się okazuje, prostota i finezja idzie w parze z doskonałym warsztatem teoretycznym.

Ken Wilber może cieszy się zasłużoną sławą w Ameryce, gdzie każda jego kolejna książka jest wielkim wydarzeniem, jednak w Polsce jest on, pomimo wydanych książek, myślicielem słabo znanym. Wynika to z dość nietypowego usytuowania samego Wilbera w tradycji myśli współczesnej z jednej strony, z drugiej zaś z faktu, że myśl integralna stawia każdego czytelnika jego pism przed koniecznością zajęcia własnego stanowiska w przepastnej tematyce duchowej naszych czasów.

Ten szkic ma także udzielić odpowiedzi na pytanie, czy integralna filozofia kultury sprosta zadaniu, gdy idzie o zaplecze ideowe i teoretyczne dla teorii edukacji. Chciałbym spróbować przełożyć język twórcy modelu integralnego Kena Wilbera na język toczących się współcześnie debat edukacyjnych. Myślę jednak, że praktycy edukacji wiele mogą skorzystać z debat rozgrywających się w Ameryce, skąd pochodzi idea integralnej edukacji. Co warto od razu podkreślić, zadanie nie będzie łatwe, gdyż niejasne jest społeczne zakorzenienie ruchu integralnego w Polsce. Ken Wilber przekonuje w pracy Integralna teoria wszystkiego (2006), że 
możliwe jest stworzenie integralnej edukacji, podobnie jak medycyny integralnej czy też ekologii integralnej, a nawet i polityki. I właśnie w prężnych instytutach integralnych w Ameryce tworzenie ruchu integralnego w edukacji staje się wyzwaniem dla praktyków. Co zauważyłem już wcześniej, nauka w ponowoczesności utraciła powagę (Lyotard, 1997) i wydaje się dzisiaj, że wszelkie „wielkie narracje” nie mają racji bytu. To samo dotyczy filozofii integralnej, która od kilkunastu już lat domaga się "głosu” i „pełnoprawnego" uczestnictwa w debacie wokół budowy alternatywy dla wyczerpującej się misji szkoły operującej z poziomu pierwszego poziomu. Kryzys legitymizacji i reprezentacji wiedzy pozwala Denzinowi i Lincoln (2009) w ogóle nie rejestrować faktu pojawienia się alternatywy w postaci ruchu integralnego, w momencie prezentacji dominujących dyskursów społecznych. Tak więc komplikuje się raczej szansa i możliwość zakorzenienia społecznego filozofii integralnej Kena Wilbera. Potrzebna jest zatem akcja promocyjna i wzmocnienie przesłania twórcy Psychologii integralnej (2002). Wydaje się jednak, że znaczącym wkładem w rozwój teoretycznych podstaw dla edukacji integralnej może być koncepcja integralnego rozwoju, a szczególnie adresowana do ludzi wrażliwych i samodzielnych idea integralnej praktyki życiowej jako wehikułu rozwoju osobistego i wzrastania wzwyż po spirali rozwoju.

Zdaniem Wilbera równie ważnym elementem, obok prezentowanych elementów teorii integralnej, jest skuteczna praktyka integralna, umożliwiająca z jednej strony ewolucję świadomości indywidualnej do poziomu integralnego, jak również dokonanie się wielkiej transformacji kulturowej do postaci prawdziwie integralnej kultury. Tutaj oczywiście pojawia się miejsce na prezentację poglądów Wilbera na temat natury integralnego rozwoju oraz prezentacja ewolucji jego poglądów na temat praktyk umożliwiających dokonanie tej wielkiej transformacji. Dalsza część tekstu zmierza do wskazania należnego miejsca dla koncepcji Integralnej Praktyki Życiowej jako modelu praktyki i sztuki integralnego życia - to cenny wkład Wilbera w genealogię rozwoju zachodnich technik siebie.

Począwszy od pracy Jeden smak (1999), Wilber prezentuje swoje przemyślenia na temat praktyk wspierających ewolucję świadomości do poziomu integralnego, które nazywa tam praktykami transformującymi. W wydanej później pracy Integralna teoria wszystkiego Wilber posługuje się określeniem integralna praktyka transformujaca. Natomiast od momentu pojawienia się pracy The Integral Vision, a miało to miejsce w roku 2007, posługuje się na określenie praktyki integralnej nazwą integralna praktyka życiowa. W roku 2008 Wilber wraz z innymi autorami wydał pracę Integral Life Practice, w całości poświęconej sztuce życia integralnego.

Koncepcja integralnego rozwoju jest twórczym podejściem do zagadnienia rozwoju człowieka, oddając sprawiedliwość wszystkim ważnym dla zrównoważo- 
nego i spójnego rozwoju wymiarom egzystencji człowieka. To wizja łącząca spójny rozwój na wielu polach czy w wielu aspektach jednocześnie. Idea integralnego rozwoju oparta jest na modelu pracy nad całościowym planem ludzkiego życia, w wymiarze: jaźni, kultury i natury.

Wyraża również zaufanie do ludzkiego potencjału kreacji własnej integralnej praktyki życiowej, która musi opierać się na własnym, indywidualnym projekcie i aktywnościach zgodnych z tą unikalną perspektywą życiową. Jest tu zawsze otwarte pole do eksploracji i rozwiązań zgodnych z praktykowanymi w życiu aktywnościami, a rola integralnego poglądu polega na łączeniu tych aktywności w model przemyślany i na tyle integralny, jaki jest tylko możliwy. Jeśli więc praktykujesz medytację, to rozwój integralny pokaże ci dodatkowe pole aktywności w obszarze kultury i natury.

Jak pisze Wilber w Integralnej teorii wszystkiego: „Zasadnicza idea integralnej praktyki transformującej jest prosta: im więcej aspektów naszego bytu jednocześnie ćwiczymy, tym bardziej prawdopodobna jest transformacja. Innymi słowy, IPT powinna w jak największym stopniu obejmować «wszystkie kwadranty, wszystkie poziomy»" (Wilber, 2006b: 214-215). Tak pisze następnie: „Mówiąc o «wszystkich poziomach», mam na myśli fale istnienia: od materii poprzez ciało, umysł, duszę do ducha; «wszystkie kwadranty» odnoszą się natomiast do wymiarów «ja», «my», «to» (inaczej do jaźni, kultury i natury; sztuki, zagadnień moralnych i nauki; pierwszej, drugiej i trzeciej osoby). A zatem praktykowanie «wszystkich kwadrantów, wszystkich poziomów» obejmuje ćwiczenie fal fizycznych, emocjonalnych, mentalnych i duchowych w jaźni, kulturze i naturze" (Wilber, 2006b: 215).

Celem Integralnej Praktyki Życiowej [Integral Life Practice] jest uświadomienie sobie pełnego spektrum swoich wyjątkowych i specjalnych zdolności. Dzięki codziennej praktyce na wielu arenach czy modułach możesz doświadczyć większej wolności i pełni swojego życia.

Podstawa ILP jest prosta; jeśli weźmiesz ciało, umysł i ducha (jako poziomy) i jaźń, kulturę i naturę (jako ćwiartki), a następnie stworzysz kombinacje, wtedy otrzymasz dziewięć możliwych przestrzeni wzrostu i przebudzenia. ILP jest pierwszym podejściem do kombinacji ich wszystkich dla bardziej efektywnej transformacji osobistej. Dlatego w innych pracach Wilber pisze o praktykach transformacyjnych (inna nazwa dla ILP). Jeśli weźmiemy trzy poziomy (ciało, umysł i duch) w czterech ćwiartkach, to otrzymamy 12 przestrzeni. ILP stworzyła praktyczne ćwiczenia dla wzrostu we wszystkich 12 wymiarach, co jest radykalnie unikalnym i bez precedensu w historii podejściem do wzrostu, rozwoju i przebudzenia. Każdy może stworzyć własną ILP, która okaże się efektywna. ILP wyraża się w czterech podstawowych (core) modułach: Ciało, Umysł, Duch i Cień. AQAL - wszystkie 
ćwiartki (ja, my, to) i wszystkie poziomy (ciało, umysł, duch). Oznacza to doświadczanie i kultywowanie ciała, umysłu i ducha w jaźni, kulturze i naturze. Inaczej mówiąc, to, co zrealizowane w jaźni, ucieleśnione jest w naturze i wyrażone w kulturze (Wilber, 2006b: 217).

Jak pisze Wilber, rozwojowe modele ogólnie zgadzają się z tym, że ludzie od urodzenia przechodzą przez serię stadiów czy fal rozwojowych: „Niższe, wcześniejsze stadia są wstępnymi, częściowymi i fragmentarycznymi poglądami na świat, podczas gdy wysokie stadia są zintegrowane, rozumiejące i holistyczne. $\mathrm{Z}$ tego powodu wczesne stadia często nazywane są pierwszym rzędem, a wyższe stadia nazywane są drugim rzędem" (Wilber, Patten, Leonard, Morelli, 2008: $\mathrm{XV}$ ). Jak pisze: „Na integralnych stadiach rozwoju wewnętrzny świat zaczyna mieć znaczenie, łączy się, i właśnie pojawia się jako «uni-verse» - «jeden świat» - pojedynczy, zjednoczony i zintegrowany świat, który łączy nie tylko różne filozofie i idee o świecie, ale także różne praktyki wzrostu i rozwoju" (Wilber, Patten, Leonard, Morelli, 2008: XV). Celem integralnej praktyki życiowej jest ogarnięcie wszelkich płaszczyzn, na których przejawiają się możliwości wzrostu i rozwoju.

Jak pisze: „Integralna Praktyka Życiowa jest taką zintegrowaną praktyką, praktyką, która pomoże ci wzrastać i rozwijać się do twoich pełnych potencjałów - do twojej wewnętrznej Wolności i największej Pełni w świecie całej okazałości (w związkach, pracy, duchowości, karierze, w grze, w życiu samym)" (Wilber, Patten, Leonard, Morelli, 2008: XV). Integralna Praktyka Życiowa zawiera wszystkie wymiary istnienia (fizyczny, emocjonalny, umysłowy i duchowy w jaźni, kulturze i naturze). Działanie praktyki oparte jest na współzależności i synergii. Jak pisze: „(...) współzależność (cross training) w sposób radykalny przyspiesza rozwój wszystkich wymiarów - ciała, umysłu, ducha i cienia - angażując szybsze, bardziej efektywne, bardziej wydajne praktyki” (Wilber, Patten, Leonard, Morelli, 2008: XVI).

Prezentowane wyżej rozważania dotyczą instytucji integralnej praktyki życiowej, w której integralną część stanowi moduł Ciało, który włączyć trzeba w projekt integralnego rozwoju. Jednak, jak postaram się wykazać, ciało stanowi problem dla wielu badaczy współczesnych, a według Kena Wilbera rozwiązanie możliwe jest projekcie integralnego rozwoju.

Zdaniem Wilbera głównym problemem, którego rozwiązanie jest możliwe dzięki podejściu integralnemu (podejściu wszystkich poziomów, wszystkich ćwiartek), jest to, co Schopenhauer nazywał „węzłem świata”, mianowicie problem umysłu-ciała (Wilber, 2002: 213), a poza tym „znaczna część problemu umysłu-ciała jest wytworem płaskiej Ziemi” (Wilber, 2002: 213). 
Chciałbym przytoczyć kilka fragmentów z pracy Kena Wilbera Psychologia integralna dla zilustrowania tego poglądu, który, zdaniem Wilbera, wykazuje ekspansję naukowego podejścia oraz zmierza do wykluczenia elementów pierwszej ćwiartki (intencjonalnej), do wykluczenia obszarów subiektywnych w naukowym dyskursie (analiza górnej prawej ćwiartki - behawioralna).

Wilber w następujący sposób precyzuje swój pogląd: „Nie rozróżnienia umysłu i ciała, które jest co najmniej tak stare jak cywilizacja i nigdy nikogo wcześniej nie niepokoiło, lecz rozdzielenia umysłu i ciała, które jest szczególną zmianą chorobową w świadomości modernistycznej i postmodernistycznej, towarzyszącą skurczeniu się Kosmosu w płaską Ziemię" [wyróżn. J.M.] (Wilber, 2002: 213). Dodaje zaraz: „Jest tak, bowiem na płaskiej Ziemi napotykamy uporczywy dylemat związany z relacją umysłu i ciała: dla umysłu (świadomości, uczucia, myśli, przytomności) - krótko mówiąc, dla obszarów Lewej Ręki - nie ma miejsca w świecie opisywanym wyłącznie w kategoriach Prawej Ręki (materialnego ciała i mózgu) i umysł staje się «duchem w maszynie»" (Wilber, 2002: 213). W pełni zgadzam się w Wilberem, gdy pisze: „Stajemy zatem wobec dwóch najwyraźniej oczywistych, lecz sprzecznych prawd: prawdy bezpośredniego doświadczenia, które mówi mi nieomylnie, że świadomość istnieje, oraz prawdy nauki, które mówi mi nieomylnie, że świat składa się wyłącznie z układów podstawowych jednostek (kwarków, atomów, strun itd.), które nie mają żadnej świadomości i żaden nowy układ tych bezrozumnych jednostek nie da w rezultacie umysłu" (Wilber, 2002: 213). Zdaniem Wilbera problem ten (to znaczy ciała i umysłu) znajduje wiele rozwiązań, ale dominują dwa: dualizm i fizykalizm. Postawa dualistyczna wywierała największy wpływ na początku ery modernistycznej (od Kartezjusza do Leibniza); natomiast później i do dziś przeważa pogląd fizykalny.

Postaram się scharakteryzować za Wilberem te dominujące rozwiązania oraz zaprezentuję rozwiązanie integralne problemu, jako najbardziej wyważone i zaawansowane, jakim dysponujemy na progu XXI wieku. Wilber charakteryzuje pogląd fizykalny w następujący sposób: „Według podejścia fizykalnego (lub materialistycznego) istnieje tylko wszechświat fizyczny, najlepiej opisany przez fizykę i inne nauki przyrodnicze, i nigdzie w tym fizycznym wszechświecie nie znajdujemy świadomości, umysłu, doświadczenia ani przytomności. Te «doznania wewnętrzne» są jedynie złudzeniami (lub w najlepszym razie produktami ubocznymi pozbawionymi jakiejkolwiek autentycznej realności)” (Wilber, 2002: 214). Jak pisze Wilber:

W mojej terminologii ta argumentacja brzmi tak: wszystkie obiektywne systemy opisywane są w języku «to», natomiast doświadczenie, świadomość i właściwości opisywane w języku „ja”, więc jeśli wierzymy, że świat opisywany przez naukę jest światem „rzeczywi- 
ście rzeczywistym" - a jest przecież wiele słusznych powodów, by sądzić, że właśnie nauka daje nam największe nadzieje na odkrycie prawdy - wówczas naturalnie musimy wierzyć, że właściwości, doświadczenie i świadomość nie sq „rzeczywiście rzeczywiste”, lecz są złudzeniami lub produktami ubocznymi albo drugorzędnymi cechami rzeczywistego świata ukazanego przez naukę. (Wilber, 2002: 214-215)

Dualiści natomiast przekonują, że istnieją dwa byty: świadomość i materia. Jak pisze Wilber:

Ale (...) dualiści stają przed odwiecznym dylematem: jak dwie całkowicie różne rzeczy mogą na siebie wpływać? Duchy, jak wszyscy wiemy, nie przesuwają ścian, lecz przez nie przenikają, więc jak duchowy umysł może wywierać jakiś rzeczywisty wpływ na materialne ciało? Samo wykazanie, że umysł nie może zostać sprowadzony do materii, odbiera dualistom możliwość objaśnienia, jak umysł może oddziaływać na materię. Dlatego wielką trudność sprawia im wyjaśnienie choćby tego, dlaczego mogę ruszać ręką. (Wilber, 2002: 216)

\section{Zdaniem Wilbera}

część (...) trudności wynika z faktu, że oba główne stanowiska przyjęły terminy płaskiej Ziemi i próbują nimi żonglować, aby uzyskać rozwiązanie, które, z czym praktycznie wszyscy się zgadzają, nie jest zadowalające. Jeśli natomiast użyjemy podejścia „wszystkich poziomów, wszystkich ćwiartek”, od razu zauważamy, że „umysł” i „ciało” mają dwa bardzo różne znaczenia, co pokazuje, że w jednym problemie w rzeczywistości kryją się cztery problemy. (Wilber, 2002: 216-217)

Ogólnie problem ten Ken Wilber ilustruje w ten sposób:

Po pierwsze, „ciało” może oznaczać biologiczny organizm jako całość, włączając w to mózg (korę nową, system limbiczny, pień mózgu itd.) - inaczej mówiąc, „ciało” może oznaczać całą Górną Prawą ćwiartkę, którą będę nazywał „ organizmem”. Organizm będę nazywał „Ciałem” (...). Zatem mózg znajduje się w Ciele, co jest powszechnie akceptowanym poglądem naukowym (i ścisłym opisem Górnej Prawej ćwiartki). (Wilber, 2002: 217)

Ale - jak pisze - „ «ciało» może również oznaczać i dla przeciętnej osoby rzeczywiście oznacza subiektywne uczucia, emocje i doznania odczuwanego ciała” (Wilber, 2002: 217). To drugie rozumienie „ciała” według Wilbera lokuje się w Górnej Lewej ćwiartce. Rezultatem redukcjonizmu płaskiej Ziemi jest fakt, że:

Gdy Kosmos zostaje zredukowany do płaskiej Ziemi (naturalizm, fizykalizm, materializm naukowy), wewnętrzne zjawiska obszaru ,ja" nadal sq̨ odczuwane i silnie odbierane intuicja (umysł może kontrolować ciało, mamy pewien stopień wolnej woli, mamy świadomość, 
istnieje jedność doświadczenia), ale te zjawiska skonfrontowane są ze światem uważanym za całkowicie realny, w którym istnieją tylko opisywane przez naukę zjawiska „to”. (Wilber, 2002: 219)

Kolejną ważną dystynkcją w problemie rozróżnienia ciała Ken Wilber prezentuje w ten sposób:

istnieje różnica między umysłem (formop) i odczuwanym ciałem (witalnym i czuciowo-ruchowym). Tej różnicy można doświadczyć we wnętrzu, czyli w obszarach Lewej Ręki. Nie jest to dualizm, lecz raczej przypadek „przekraczania i włączania” i niemal każdy racjonalnie myślący dorosły odczuwa tę przekraczającą część, w tym sensie, że umysł, kiedy dobrze się czujemy, może kontrolować ciało i jego pragnienia. Ale kiedy „ciało” oznacza organizm Prawej Ręki, a „umysł” oznacza mózg Prawej Ręki, wszystkie wewnętrzne etapy jakościowego rozwoju (od ciała przez umysł i duszę do ducha) są pominięte - wszystkie te jakościowe rozróżnienia całkowicie giną w materialnym monizmie, który nie rozwiązuje problemu, lecz go wymazuje. (Wilber, 2002: 220)

\section{Jak zauważył Wilber:}

Dualista (...) uznaje realność zarówno świadomości, jak i materii, ale na ogół nie ma nadziei ich połączyć. „Umysł” rozumiany ogólnie jako to, co „wewnętrzne”, i „Ciało” rozumiane ogólnie jako to, co „zewnętrzne”, wydają się rozdzielone nieprzebytą przepaścią - dualizmem podmiotu i przedmiotu. (Wilber, 2002: 220)

Aby rozwiązać zarysowany problem, należy rozważać go z perspektywy integralnej. Według Wilbera rozwiązanie przynosi jedynie uznanie transracjonalnych etapów rozwoju. Jak dodaje Wilber: „rozwiązać go można wyłącznie na postracjonalnych etapach rozwoju - etapach generalnie traktowanych z podejrzliwością, ignorowanych lub aktywnie negowanych przez większość racjonalistycznych badaczy" (Wilber, 2002: 221). Natomiast w perspektywie integralnej, według Wilbera:

Podmiot i przedmiot są zarówno odrębnymi bytami, jak $i$ aspektami tej samej rzeczy: prawdziwa jedność w różnorodności. Ale tej jedności w różnorodności nie można wyrazić racjonalnymi terminami w sposób mający sens dla osoby, która nie doznała doświadczenia transracjonalnego. Zatem ci, którzy pragną uzyskać „dowód” tego nieudalnego rozwiązania, mogą go znaleźć jedynie w dalszym rozwoju własnej świadomości. Chociaż to rozwiązanie („musisz dalej rozwijać swoją świadomość, jeśli chcesz poznać jej pełne wymiary") nie zadowala racjonalisty (czy to dualisty, czy fizykalisty), niemniej zgodnie $\mathrm{z}$ autentycznie integralnym paradygmatem jest jedynym możliwym do przyjęcia. (Wilber, 2002: 221) 
Zdaniem Wilbera „rozwiązanie węzła świata” „dokonuje się poprzez odsłonięcie postracjonalnych, niedualnych etapów rozwoju świadomości” (Wilber, 2002: 222). Istota integralnego podejścia do problemu umysłu-ciała zawarta jest $\mathrm{w}$ dwóch fazach. Zdaniem Wilbera:

pierwsza polega na przejściu od opisów redukcjonistycznych do obejmujących wszystkie ćwiartki. Uznanie czterech ćwiartek (lub po prostu Wielkiej Trójki) pozwala na włączenie na równych prawach fenomenologicznych relacji $w$ pierwszej osobie (,ja”), intersubiektywnych kontekstów drugiej osoby („my”) i fizycznych systemów trzeciej osoby („to”) - będziemy to nazywali „1-2-3 badań nad świadomością”. (Wilber, 2002: 223)

Druga faza, zdaniem Wilbera, „polega na przejściu od ujęcia obejmującego „wszystkie ćwiartki” do ujęcia obejmującego „wszystkie poziomy, wszystkie ćwiartki” (Wilber, 2002: 223). Jak konkluduje Wilber:

(...) ogromna ilość danych - przedmodernistycznych, modernistycznych i postmodernistycznych - wskazuje wyraźnie na podejście integralne, obejmujące wszystkie ćwiartki i wszystkie poziomy. Całość tych danych wskazuje jednoznacznie na fakt, że jesteśmy dziś bliscy może jeszcze nie ukształtowania kompletnego i integralnego obrazu świadomości. Lecz uświadomienia sobie, że nic innego nas już nie zadowoli. (Wilber, 2002: 228)

W rozważaniach prezentujących pogląd integralny Kena Wilbera dążyłem do ukazania realnych niebezpieczeństw podejścia redukcyjnego oraz jednocześnie do przybliżenia podejścia opartego na modelu AQAL, aby wskazać rozwiązanie tego „węzłowego problemu” nowożytnej filozofii zachodniej.

\section{Zakończenie}

Moim zdaniem nie wystarczy już dzisiaj krytyka kultury konsumenckiej ani absurdów kultury eksperckiej - i to jest apel do pedagogów - powinnością jest natomiast prezentowanie „podejścia pozytywnego”, bowiem ostrze krytyki często sieje spustoszenie, wątpliwości i odbiera nadzieję, że podjęty trud ma jakikolwiek sens. Zawarte w poradnikach rozwoju świadomości ciała porady, a także filozofia ruchu makeover (modelowanie ciała), oparta na ideale ciała „pięknego, szczupłego i młodego", traktowanie ciała jako tekstu, czego przejawem jest tatuaż, makijaż, ozdoba, również rytualne skrywanie ciała ze względu na płeć, religię czy chorobę, ma swe dopełnienie w kulturowej utopii agelessu, a więc w pogoni za ideałem w odrzuceniu choroby, szpetoty, starości czy kalectwa. 
Ruch społeczny promujący zdrowie i cielesność może natrafić na opór przed poddaniem się nakazom autorytetów kulturowych i przeobrazić się w społeczne nieposłuszeństwo, co prowadzi do zguby, a filozofia carpe diem może prowadzić do poruszania po kruchym lodzie samozagłady. Moim zdaniem warto też, a może przede wszystkim, promować zjawiska zmierzające w kierunku wykraczającym poza negację kultury. Wilber od lat skutecznie promuje na Zachodzie stanowisko integralne. Integralna duchowość, obejmująca ciało, to duchowość afirmująca ciało poprzez praktyki angażujące pełnię człowieka, człowieka integralnie zmierzającego ku pełni człowieczeństwa. Jakże ubogie wydają się praktyki wyrosłe w głównym nurcie kultury konsumenckiej - także te ostatnio ukazujące się w ruchu makeover, filozofii transhumanizmu, filozofii posthumanizmu oraz perspektywa klonowania.

Ken Wilber, znany na świecie głównie jako twórca integralnego modelu rozwoju, zaproponował nam swoją wizję integralnych praktyk życiowych (ILP - Integral Life Practices), a więc modelu życia świadomego, w którym nasze codzienne aktywności zorganizowane zostają w pracę nad długofalowym rozwojem. Jednak, jak wszyscy wiemy, to przestroga Wilbera, mapy nie należy mylić z terytorium, które opisuje.

Podobnie jest ze sprawą rozwoju. Owszem, pewne wskazówki praktyczne są oczywiście potrzebne; niemniej jednak zasadnicza sprawa sprowadza się raczej do materii naszego niepowtarzalnego istnienia i naszej sytuacji, słowem, wiele zależy od naszego rozumienie tego przesłania czy instrukcji. Nabierają one znaczenia dopiero w perspektywie naszego specyficznego egzystencjalnego i społecznego zakotwiczenia. Nie chcę przez to powiedzieć, że lektura prac Wilbera jest niepotrzebna. Owszem, można traktować opisane przez niego sprawy jako rodzaj przewodnika po terytorium duchowym, niemniej sytuacja naszego niepowtarzalnego położenia życiowego sprawia, że niezależnie od tego powinniśmy zdecydowanie trzymać się naszego unikalnego kontekstu. W zasadzie dla życia świadomego nie ma żadnej alternatywy. Nawet piękny Disneyland okazuje się jedynie namiastką wobec atrakcji życia w pełni przebudzonego. My, ludzie Zachodu, zbyt wiele uwagi poświęcamy na eksploracje świata zewnętrznego, zaniedbując świat wewnętrzny. Dowodem na to jest wybujała technologicznie cywilizacja. Tymczasem na Wschodzie uwaga skierowana jest do wnętrza. Tylko „odyseja umysłu”, którą podejmujemy, zaowocuje wolnością. Życie przebudzone jest możliwe, czego dowodzi tradycja praktyk duchowych.

\section{Literatura}

Bachmann-Medick D. (2012). Cultural Turns. Nowe kierunki w naukach o kulturze. Warszawa. Barker Ch. (2005), Studia kulturowe. Teoria i praktyka. Kraków. 
Bauer W. (2004). Tożsamość i przemiany społeczne - przegląd teoretycznych stanowisk. „Teraźniejszość - Człowiek - Edukacja" nr 1.

Bauman Z. (1995) Ciało i przemoc w obliczu ponowoczesności. Toruń.

Bauman Z. (1996). Etyka ponowoczesna. Warszawa.

Bauman Z. (2006). Płynna nowoczesność. Kraków.

Block S.H, Block C. (2011). Powrót do zmystów. Warszawa.

Błajet P. (2006). Ciało jako kategoria pedagogiczna: w poszukiwaniu integralnego modelu edukacji. Toruń.

Butler J. (2011). Ramy wojny. Warszawa.

Csikszentmihalyi M. (1995). Przeplyw. Psychologia optymalnego przeplywu. Taszów.

Denzin N., Lincoln Y. (1997). Wprowadzenie w pole badań jakościowych. „Socjologia Wychowania” z. 317 .

Giddens A. (2006). Tożsamość i nowoczesność. „Ja” w społeczeństwie późnej nowoczesności. Warszawa.

Gromkowska A. (2000). Kobieta epoki wiktoriańskiej: społeczne konstruowanie ciała i tożsamości. „Teraźniejszość - Człowiek - Edukacja” nr 4.

Jacyno M. (2007). Kultura indywidualizmu. Warszawa.

Kabat-Zinn J. (2008). Dary codzienności. Warszawa.

Kabat-Zinn J. (2009). Życie - piękna katastrofa. Warszawa.

Marzec J. (2002). Dyskurs, tekst i narracja. Szkice o kulturze ponowoczesnej. Kraków.

Marzec J. (2010). O samorealizacji w epoce instant. „Teraźniejszość - Człowiek - Edukacja” nr 2.

Marzec J. (2011a). Ken Wilber - pasja rozwoju. „Przegląd Pedagogiczny” nr 2.

Marzec J. (2011b). Polityka religijności w epoce instant. „Forum Oświatowe” nr 2.

Marzec J. (2012). Duchowość, tożsamość i edukacja. „Forum Oświatowe” nr 2.

Melosik Z. (1996). Tożsamość, ciało i władza. Teksty kulturowe jako (kon)teksty pedagogiczne. Poznań-Toruń.

Melosik Z. (red.). (1999). Ciało i zdrowie w społeczeństwie konsumpcji. Poznań.

Melosik Z. (2006). Kryzys męskości w kulturze współczesnej. Kraków.

Melosik Z. (2010). Tożsamość, ciało i władza w kulturze instant. Kraków.

Pawłucki A. (1994). Kulturowy paradygmat w pedagogice ciała. „Nieobecne Dyskursy” nr 4, s. 99 115.

Pawłucki A. (2001). Nauczyciele wobec ponowoczesnego kultu ciała uczniów. „Edukacja” nr 1.

Wilber K. (1995). Śmiertelni, nieśmiertelni. Warszawa.

Wilber K. (1996). Niepodzielone. Wschodnie i zachodnie teorie rozwoju osobowości. Poznań.

Wilber K. (1997). Eksplozja świadomości. Zabrze.

Wilber K. (1998). Krótka historia wszystkiego. Warszawa.

Wilber K. (1999). Jeden smak. Warszawa.

Wilber K. (2003). Psychologia integralna. Warszawa.

Wilber K. (2006a). Integral Spirituality. Boston-London.

Wilber K. (2006b). Integralna teoria wszystkiego. Poznań.

Wilber K. (2007). The Integral Vision. Boston-London.

Wilber K. (2008). Małżeństwo rozumu z duszą. Warszawa.

Wilber K. (2010). Boomeritis. Warszawa.

Wilber K., Patten T., Leonard A., Morelli M. (2008). Integral Life Practice: A 21-st Century Blueprint for Physical Health, Emotional Balance, Mental Clarity, and Spiritual Awekening. Boston-London.

Williams M., Teasdale J., Segal Z., Kabat-Zinn J. (2013). Świadomą drogą przez depresję. Warszawa. 